\title{
Effect of bio-priming and colonized FYM with bio-control agents on quantative and qualitative traits and disease management in barnyard millet (Echinochloa crusgalli L.)
}

\author{
Laxmi Rawat*, Ankit Tewari, T.S. Bisht ${ }^{1}$, Shambhoo Prasad and Vikas Yadav ${ }^{2}$ \\ College of Forestry (V.C.S.G. Uttarakhand University of Horticulture and Forestry), \\ Ranichauri (Uttarakhand) India \\ (Email : laxmirawatpathology@gmail.com)
}

\begin{abstract}
The present investigation was conducted during Kharif, 2016 at Research B-Block, Plant Pathology Division, College of Forestry, Ranichauri, V.C.S.G. Uttarakhand University of Horticulture and Forestry. The treatments included bio-agents applied through seed bio-priming alone or in combination with FYM colonized by bio-agents and fungicide (seed treatment with fungicide carbendazim) for assessment of morpho-physiological traits and disease management in barnyard millet var. PRJ-1. Maximum number of leaves per plant, stem diameter, number of effective tiller plant ${ }^{-1}$, plant height, number of fingers ear ${ }^{-1}$, ear length, ear diameter, 1000 grain weight, biological yield, grain yield plant ${ }^{-1}$ and grain yield was recorded in treatment $\mathrm{T}_{5}$ (Seed bio-priming with Trichoderma asperellum Th-14+FYM colonized by Th-14) followed by $\mathrm{T}_{8}$ (Seed bio-priming with Pseudomonas fluorescens Psf4+FYM colonized by Psf-4) while, minimum was recorded in $\mathrm{T}_{10}$ (control). Similarly $\mathrm{T}_{5}$ (Seed bio-priming with Trichoderma asperellum Th-14+FYM colonized by $T h-14$ ) also showed minimum days to 50 per cent flowering, days to maturity and disease (Sheath blight and brown leaf spot) incidence than other treatments including control. From the present investigation, it may be concluded that the tested bio-agents applied through seed bio-priming alone or in combination with FYM pre-colonized by bioagents enhanced the growth parameters, yield and its contributing traits as well as reduced disease severity in barnyard millet (var. PRJ-1) though the performance of the treatment $\mathrm{T}_{5}$ (Seed bio-priming with Trichoderma asperellum Th-14+ FYM colonized by $T h-14$ ) was found better among all the treatments for most of the parameters studied under present environmental materials and conditions.
\end{abstract}

Key Words : Bio-priming, Disease management, Bio-control agent

View Point Article : Rawat, Laxmi, Tewari, Ankit, Bisht, T.S., Prasad, Shambhoo and Yadav, Vikas (2018). Effect of bio-priming and colonized FYM with bio-control agents on quantative and qualitative traits and disease management in barnyard millet (Echinochloa crusgalli L.). Internat. J. agric. Sci., 14 (2) : 335-343, DOI:10.15740/HAS/IJAS/14.2/335-343. Copyright@2018: Hind Agri-Horticultural Society.

Article History : Received : 22.01.2018; Revised : 23.04.2018; Accepted : 09.05.2018

\footnotetext{
* Author for correspondence:

${ }^{1}$ Krishi Vigyan Kendra (V.C.S.G. Uttarakhand University of Horticulture and Forestry), Ranichauri (Uttarakhand) India

${ }^{2}$ Central Horticultural Experiment Station (ICAR-CIAH), Vejalpur, Panchmahals (Gujarat) India
} 